\title{
THE CYBER-PHYSICAL SYSTEM FOR COULOSTATIC EXPERIMENT. THE CORROSION MONITORING UNIT
}

Annotation. Cyber-physical approach shows new perspectives in solution of actual problem of computerized corrosion monitoring. It was analyzed for special case of the coulostatic technique used for determination of corrosion rate. Basic problems concerning polarization control, computing of relaxation equations, simulation of hydrodynamic mode were revealed.

Key words: cyber-physical system, electrochemistry, corrosion, simulation, measurement.

1. Introduction. In previous paper mathematical model and corresponding computer application for determination of adsorption characteristics in coulostatic experiments on solid electrodes were described [1]. Following article was devoted to analysis of effectiveness of cyber-physical systems (CPS) in electrochemical measurements. It was shown that measurements connected tightly environment, computation and communication; the whole system is multi-dynamic, with feedback interaction between 'cyber' and 'physical' parts; volume of data to be processed is unlimited in many cases.

The term 'cyber-physical systems' refers to integration of computation with physical processes [4]. Usually, the term used to describe embedded systems as well as networks monitoring and controlling physical processes which, through feedback circuits, can affect computation flows. They combine cyber capabilities (communication, computation and control) with physical capabilities (sensing and actuation) to solve problems that neither part could solve alone. Many contemporary experiments in sciences, in particular in physics, require the observation of experiment outcomes with IT devices. The combination of physical experiments and IT devices can be seen as a special case of CPS [3].

2. The problem. Methods and devices for estimation of corrosional losses or corrosion rate constitute the basis of the corrosion monitoring. The simplest method is the measurement of the mass losses for check samples. Nevertheless, even thou it produces most relying data, it is time-consuming, laborious and demonstrates poor

(C) Kapitonov O.G., 2021 


\section{«Системні технологіï» 4 (135) 2021 «System technologies»}

sensitivity (about 10-6 g). That is why electrochemical methods are very popular. They can be easily automated, are highly sensitive (corresponding threshold of mass losses detection is $10-9 \mathrm{~g}$ ) and allow to determine instant values of corrosion rate. Among them the techniques registering the respond for applied direct or alternative signal seem to have the best perspectives. This group that includes the polarisation resistance method, impedance spectroscopy, coulostatic and other relaxational techniques is based on assumption of direct relations between corrosion rate and such characteristics like polarization resistance $\mathrm{Rp}$ and charge transfer resistance RF.

This assumption was put forward in Stern's work [5], who introduced the concept of linear polarization for description of linear relation between the polarization current density $\Delta \mathrm{i}$ and small potential shift $\Delta \mathrm{E}$ in the region of corrosion potential Ecorr:

$$
\Delta \mathrm{E}=\mathrm{Rp} \Delta \mathrm{i}
$$

As far as relaxational methods are considered, the most appropriate definition for polarization resistance is:

$$
\mathrm{Rp}=\mathrm{Z}(\mathrm{j} 0)-\mathrm{Z}(\mathrm{j} \infty)=\operatorname{Re} \mathrm{Z}(\mathrm{j} 0)-\operatorname{ReZ}(\mathrm{j} \infty)
$$

where $\mathrm{Z}(\mathrm{j} \omega)$ is the electrochemical impedance of the system at frequncy $\omega$. In this case the whole process of corrosion rate measurement can be divided onto three stages:

1) determination of the process' mechanism, selection of corresponding definition of $\mathrm{Rp}$ and equations which depict relations between the mathematical model parameters and characteristic constants of the process;

2) determination of corresponding constants and calculation of parameters;

3) determination of $\mathrm{Rp}$ and calculation of corrosion rate.

One must note that there is plenty of factors those can change dramatically the whole scope of concepts mentioned at the first stage description: passivation, hydrodynamic mode, presence of inhibitors or other surfactants, chemical or physical inhomogeneity of corroded system, and the like. Hence, time limitations for the determination process occur and requirements to the computer system can be described in terms of requirements to the cyber-physical one. From other side, in this specific case of electrochemical measurements some functions of the CPS described 


\section{«Системні технології» 4 (135) 2021 «System technologies»}

earlier [1] become not actual; e.g., potential/current programming control, sensor preparation/renovation; others, such as thermal and hydrodynamic control, reagents input are getting more important.

3. Analysis of requirements. Corrosion monitoring refers to processes occurring on real objects, such as metal constructions, elements of cars, ships, chemical equipment and so on. Polarization of such large surfaces is often impossible. To solve the polarization proble, people use activation of smaller part of the surface or special probes made of the same material. Nevertheless, polarization generators of monitoring CPS must be rather more powerful than usual laboratory device. From other side, polarization should not change the state of the surface, that is, must be small in comparison with corrosion potential Ecorr. This means that both generators and potential registers are supposed to be elements of the unit. The system must make a decision on the optimal polarization value in each new measurement cycle. The CPS must also make decisions on selection of relevant model for corrosion process at each jump of Ecorr .

Another characteristic feature of considered electrochemical objects is dependence of their dynamics on their previous states, i.e., memory. Typical time-respond of such object may be described, for example, by equation

$$
\mathrm{K}(\mathrm{DnE} / \mathrm{Dtn})=-\mathrm{iF}
$$

where

$$
\frac{D^{n} E}{D t^{n}} \equiv \frac{1}{\Gamma(1-n)} \int_{0}^{\mathrm{t}} \frac{d E(\tau) / d \tau}{(t-\tau)^{n}} d \tau
$$

There exist a number of computing methods for calculation of functionals of (4) type, for example, ones developed by Oldham [6]. Developed 50 years ago, they correspond adequately to package technologies of computing usual for that time practice. Real-time systems, and CPS as a part of this group made creation of new methods actual task again. One approach to the problem has been elaborated by the author based on expansion of the function under study in series of functions with "good" transforms of (4) type. This routin is possible because of linearity of (3) in coulostatic case, but it is not true in common case of relaxation techniques. Linearity and possibility of measurements in low conducting media are real advantages of the coulostatic method.

One more problem of the corrosion monitoring CPS stems from dependence of corrosion products spacial distribution on hydrodynamic mode near the object's sur104 


\section{«Системні технологіï» 4 (135) 2021 «System technologies»}

face. In limiting case of zero flow the products form a film of variant density on the object's surface that might inhibit corrosion process to some degree. Other limiting case - when the flow carries the products away - is rather simple one. Direct computing with solving hydrodynamic equations does not work because of time constraints; vast literature referring the problem indicates good perspective for neural network methods in simulation of such processes. This approach seems to be fruitful even in final stage to predict moment of object's destruction.

3. Results. Cyber-physical approach shows new perspectives in solution of actual problem of computerized corrosion monitoring. It was analyzed for special case of the coulostatic technique used for determination of corrosion rate. Measurements connected tightly environment, computation and communication; basic problems concerning polarization control, computing of relaxation equations, simulation of hydrodynamic mode were revealed. Important role of neural networks in future cyber-physical monitoring systems was emphasized.

\section{REFERENS}

1. Kapitonov A.G. The computer system for coulostatic experiments. The adsorption measurements unit //System technologies. -3 (122). - Dnipro, 2019. - C. 55-58. ISSN 1562-9945

2. Kapitonov O.G. Cyber-physical systems in electrochemical measurements //System technologies. - 4(129). - Dnipro, 2020. - C.3-7. ISSN 1562-9945

3. Marwedel P. Embedded System Design. Embedded Systems, Foundations of CyberPhysical Systems, and the Internet of Things //Springer International Publishing AG, 3rd edition. ISBN 978-3-319-56045-8, 2018

4. Lee E.A. and Seshia S.A. Introduction to Embedded Systems - A Cyber-Physical Systems Approach, http://LeeSeshia.org, ISBN 978-0-557-70857-4, 2011.

5. Stern M. A method for determining corrosion rates from linear polarization data.// Corrosion.- 1958.- v.14 - №9.- P.440t-444t.

6. Oldham K., Spanier J. The fractional calculus // Academic Press, ISBN 0-12-525500,1974 .

Received 12.04.2021. Accepted 16.04.2021.

\section{Киберфизическая система кулоностатического эксперимента.}

\section{Модуль коррозионного мониторинга}

Киберфизический подход раскрывает новые перспективы в решении актуальной проблемы компьютеризованного коррозионного мониторинга. Проанализирован случай использования кулоностатического метода для определения скорости коррозии. Виявлены основные проблемы, касающиеся правления поляризацией, решения уравнений релаксации, моделирования гидродинамического режима. 
«Системні технології» 4 (135) 2021 «System technologies»

кіберфізична система кулоностатичного експеримента.

Модуль корозійного моніторингу

Кіберфізичний підхід розкриває нові перспективи у рішенні актуальної проблеми комп'ютерізованого корозійного моніторінгу. Проаналізовано випадок застосування кулоностатичного метода для визначення швидкості корозії. Виявлено основні проблеми, які стосуються керування поляризацією, рішення рівнянь релаксації, моделювання гідродинамічного режиму.

Капітонов Олександр Георгійович - доцент кафедри спеціалізованих комп’ютерних систем ДВНЗ «Український Державний хіміко-технологічний університет».

Капитонов Александр Георгиевич - доцент кафедры специализированных компьютерных систем ГВУЗ «Украинский Государственный химикотехнологический университет».

Kapitonov Oleksandr - associate professor, department of specialized computer systems, Ukrainian State University of Chemical Engineering. 